\title{
A Study of Women Perception and Preferences towards Patanjali's Personal Care Products
}

\author{
Poonam Rawat
}

Research Scholar, Department of Management Studies, Himgiri Zee University, Dehradun, Uttarakhand, India Poonamrawat33@gmail.com Mob no: 8077541465

Dr. Parikshit Kala

Assistant Professor, Department of Management Studies, Himgiri Zee University, Dehradun, Uttarakhand, India

\begin{abstract}
:
Patanjali Ayurveda Limited is a successful Indian FMCG company headquartered in Haridwar, Uttarakhand, India. There are many factors which make the success story of Patanjali Ayurveda Ltd. The brand ambassador Yoga Guru Baba Ramdev, Company’s swadeshi concept, it's product quality and fair price offered by the company and easy availability of the products in the market are few of these factors. Patanjali Ayurveda Limited deals in various products segments like food products, Health care Products and Personal Care Products. The present study has emphasized on the perception and preferences of women consumers of Patanjali Ayurveda Limited towards its personal care products. The purpose of the present study is to examine the preferences and perception of the women regarding the personal care products of Patanjali Ayurveda Limited. This paper will also attempt to investigate the women awareness level and also identify the factors which motivate a woman to purchase the personal care products of Patanjali over other brands. This study is empirical in nature and data is collected through questionnaire method by visiting Patanjali Stores in Haridwar district of Uttarakhand.
\end{abstract}

Keywords:Patanjali Ayurveda Limited, Perception and Preferences, Yoga Guru Baba Ramdev, Health Care Products.

\section{Introduction:}

In 2017, A Yoga Guru Baba Ramdev introduced a company named Patanjali Ayurveda Limited with the vision to bring the awareness of Ayurveda among the Indian public. He introduced the concept of swadeshi products which made in India from the material produced in India. Yoga Guru Baba Ramdev who is brand ambassador of Patanjali Ayurveda 
Limitedencouraged Indian people to believe again on Ayurveda treatment for the solution of their health-related problems. This company not only captured the Indian market in a very short period of time but also used the profit earn by them in social welfare. This company is providing its good quality products in fair price that's why consumers are switching their preference towards herbal and Ayurveda products of Patanjali. Its swadeshi concept attracts the consumers more and encourage them to become loyal towards Patanjali Ayurveda Limited.

\section{FMCG products of Patanjali Ayurveda Limited:}

Patanjali Ayurveda Limited manufactured more than 900 products which includes Food Products, Personal Care products and Health Care products. Its also manufactured around 300 types of Ayurveda medicine to treat many diseases. Patanjali Ayurveda Limited claimed that all the products manufactured in the company contain natural ingredients. In the present scenario this company has played vital role with commitment to providing chemical free herbal products which do not harm the health of the consumers. For this purpose, company launches many products which are renowned globally and internationally. The present study is mainly focused on the personal care product segment of Patanjali Ayurveda Limited. This study is an attempt to examine the preferences and perception of the women towards personal care products od Patanjali.

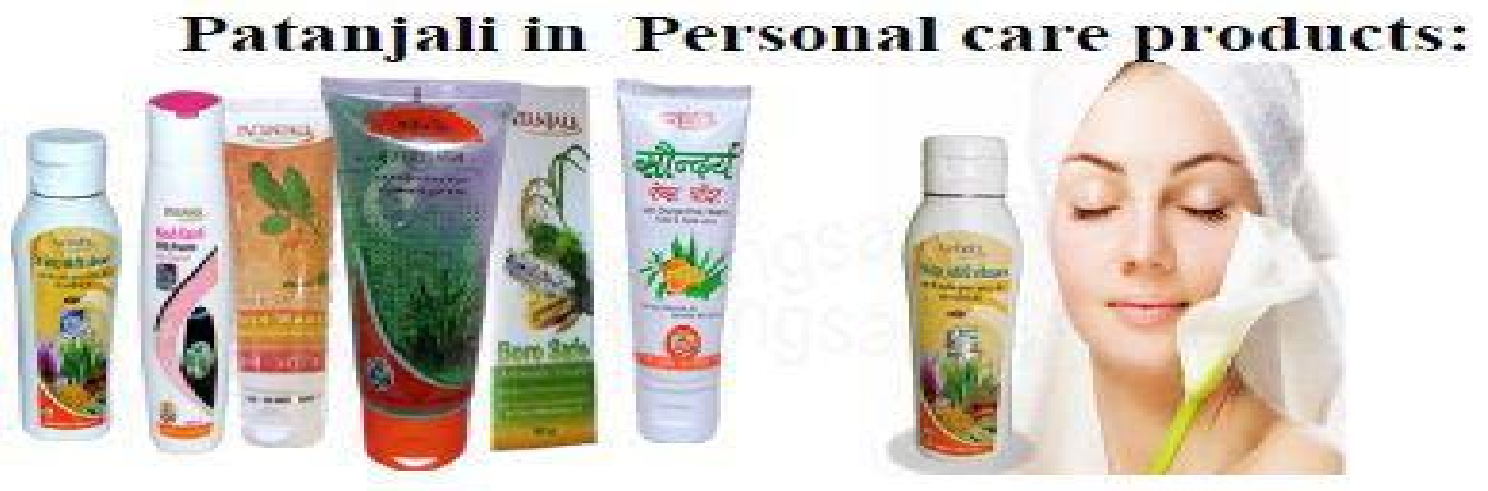

\section{Women Behaviour towards Personal Care Products of Patanjali Ayurveda Limited:}

In today's world market scenario, buyer is the lord and shopper have to understand their purchasing behaviour if he wants to sell his products. Seller have to satisfied the needs of the consumers. For this purpose, a manufacturer and marketer attempt to find out the answers of several questions like: what consumers buy, why consumer buy the products, and when\&where they buy these products, what are the frequency of buying the products, how 
often they use the products and after all this it is also important to know their post purchase behaviour to find out their satisfaction level and to find out will they buy the same product in future. Talking about women, the concept of beauty and cosmetic is not new for them. They always being obsessed with looking beautiful. In today's world the definition of women has been changed. They are not only home maker but also bread earner of the family. Being a working women and household chores, they go out and it cost their bad health and skin. Now a days, women prefer to use only those products which do not create any hazard to their health and show interest to buy the product even on high price. In the view of this, the present study is an attempt to examine the preferences and perception of the women regarding the personal care products of Patanjali Ayurveda Limited also to investigate the women awareness level regarding Personal Care products of Patanajli. This article also aims to identify the factors which motivate a woman to purchase the personal care products of Patanjali over other brands.

\section{Review of Literature:}

The review plays a vital role in analysing the present literature. It provides the useful information and results of the similar studies done by many researchers. The present review of literature will help to study the perception and preferences of women towards personal care products of Patanjali. It will also be helpful to investigate women awareness level regarding these products and also examine those factors which motivate a woman to purchase personal care products of Patanjali Ayurveda Limited.

According to TarangVaish(2006), majority of the customers of herbal products show their loyalty towards the brand they are using. They prefer to buy these products again and again. brand loyal. The study revealed that consumers between the age group of 18-24years perceived herbal products to be less harmful as compared to chemical based cosmetic products.

Jai Singh Parmar (2007) investigated those demographic factors which influence the use of cosmetic products. The study revealed that consumer's age, their income and occupation effect their purchasing behaviour. Researcher also concluded that consumer prefer to use home made products or herbal products over synthetic cosmetic products as they didn't harm their body. Further, it is also found that brand switching was very common habit among the consumers especially when their regular brand was not available in the market at that time.

Urvashi Makkar et al. (2007)revealed there was a huge demand of the herbal cosmetic products due to increasing population in middle class families, and increasing their income. 
These two factors majorly responsible for the boom in cosmetic industry. The study also revealed that middle class consumers have a strong and positive attitude towards herbal cosmetic products. They perceive that these products do not create any hazard to their health so that they can also prefer to purchase these products on the higher price.

Sundari and Murugan (2011)conducted a study on the women to investigate those factors which influence the purchase decision of personal care products. They revealed that women prefer to purchase the personal care products by analysing two types of benefits. In the primary benefit, women analyse the product's quality, its quantity and its price. In the secondary benefit, the women buying behaviour was influenced by the products' ingredients, its innovative features and reputation of the manufacturer in the market and product's brand name.

Ashok Yakkaldevi (2013)concluded that consumer's psychological and economic factors are not the only factors which influence their buying behaviour towards personal care products. There are many other factors too which include tradition, culture, history and values of affection and care.

Khanna, R.(2015)conducted a study to examine the perception, attitude and satisfaction level of the consumers regarding Patanjali products. Data was collected through questionnaire method from 100 respondents in Punjab. The study found that consumers were highly satisfied with the Patanjali products. The consumers perceived that Patanjali were offering its products on very reasonable price with good quality and has a curing ability.

Aliand Yadav(2015)conducted a study to find out the perception of the consumers towards herbal products and to identify the reasons why consumers are preferring herbal products over other products. This study was carried out in the three cities of Bhopal. For this purpose, researchers collected data from 60 consumers of herbal products. Results revealed that the major reason of using herbal products over other products was safety from hazards created by the chemical products. Further, it was also found that consumers had a positive attitude towards herbal products due to its no side effects on consumer's health.

According toShinde et al. (2017) Patanjali Ayurveda Limited is a very successful and leading Indian company. It has captured a huge market share at India in very short span of time. Researchers also revealed the various factors which influence the purchasing of various Patanjali products and also identify the problems faced by the consumers regarding buying Patanjali products. According to them shortage of the products in the market is one of the major problems of Patanjali products. 


\section{Objectives and Hypotheses:}

The main purpose of the present article is to understand the attitude, perception and preferences of the women towards Patanjali's personal care products and also to investigate the awareness of the women regarding these products of Patanjali. This study is also to investigate the factors which motivated a woman to purchase the personal care products of Patanjali over other brands. In view of this the objectives of the research paper are as follows:-

(1) To study the perception and preferences of women towards personal care products of Patanjali.

(2) To study the women awareness and the sources of awareness regarding personal care products of Patanjali.

(3)To investigate the factors which motivated a woman to purchase the personal care products of Patanjali over other brands.

\section{Hypotheses:}

In the light of above objectives, the hypotheses of the present research article are as follows:

Ho (1): All the women have same perception towards personal care products of Patanjali Ayurveda Ltd.

Ho (2): All the women have same reason to prefer personal care products of Patanjali Ayurveda Ltd.

Ho (3): The awareness level does not differ significantly among the women regarding personal care products of PatanjaliAyurveda Ltd.

Ho (4): All the women get motivated by the same factor to purchase personal care products of Patanjali Ayurveda Ltd.

\section{Research Methodology:}

Research Design: Descriptive research design is used in the present study.

Period of the study: The study was conducted for a period of 2 months.

Study area: The study is undertaken in Haridwar and nearby places where Patanjali stores were situated.

Sampling Method: Sampling method is a process that is adopted by a researcher while choosing sample from the population. For the present study the total 130 women were selected through accidental sampling technique.

\section{Data Collection:}

Both primary and secondary data were collected for the present study. Primary data were collected through the Questionnaire schedule. For this purpose, researcher visited the 
Patanjali stores whenever required to interview the women consumers presented at the store that time (Due to Covid Pandemic 2021, FMCG stores of Patanjali were opened as per government instruction).Secondary data were collected through the journals, books and internet. The data collection period was from $20^{\text {th }}$ April to $17^{\text {th }}$ June 2021.

\section{Data Analysis:}

Data was analysed with the help of SPSS 22.0 software. Appropriate statistical tools were applied to analyse the collected data. For Descriptive analysis Frequency, Mean, and Standard deviation and for inferential analysis t-test and Chi-Square have been applied.

\section{Data Analysis and Results:}

Descriptive Statistics:

$\underline{\text { Table-1.1 }}$

\begin{tabular}{|l|l|l|}
\hline Age of Women & Frequency & Percent \\
\hline $25-35 y r s$ & 75 & $57.69 \%$ \\
\hline $35-45 y r s$ & 36 & $27.69 \%$ \\
\hline above 45yrs & 19 & $14.62 \%$ \\
\hline Total & 130 & $100 \%$ \\
\hline
\end{tabular}

\section{Age of Women}

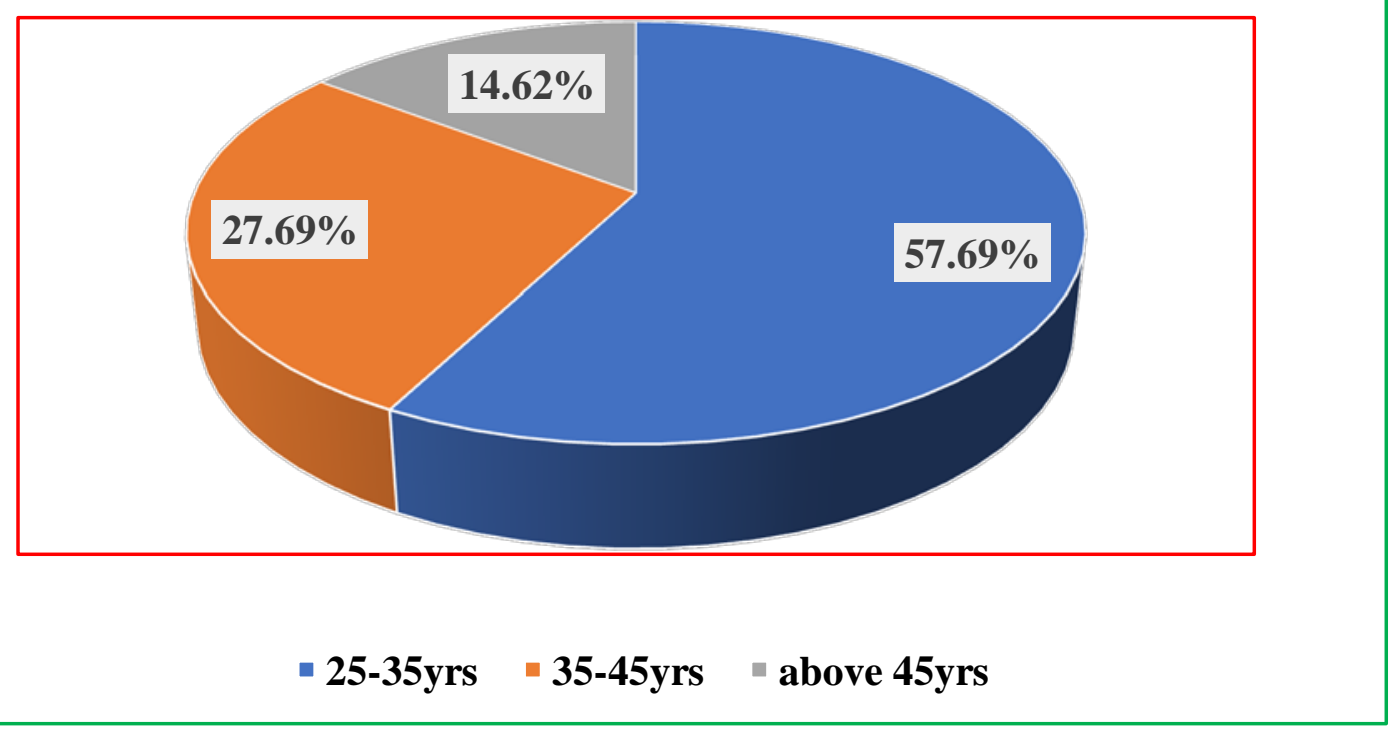


Table 1.1 shows the age of the respondents and reveals that majority of the women $(57.69 \%)$ are under 25-35 years followed by 35-45 years. Only 14.62\% women respondents are above 45 years.

\section{$\underline{\text { Table-1.2 }}$}

\begin{tabular}{|l|l|l|}
\hline $\begin{array}{l}\text { Frequency to use Patanjali's } \\
\text { personal Care Products }\end{array}$ & Frequency & Percent \\
\hline Twice a day & 39 & $30 \%$ \\
\hline Once a day & 46 & $35.39 \%$ \\
\hline Fortnight & 13 & $10 \%$ \\
\hline Monthly & 32 & $24.61 \%$ \\
\hline Total & 130 & $100.0 \%$ \\
\hline
\end{tabular}

Frequency to use Patanjali’s personal Care Products

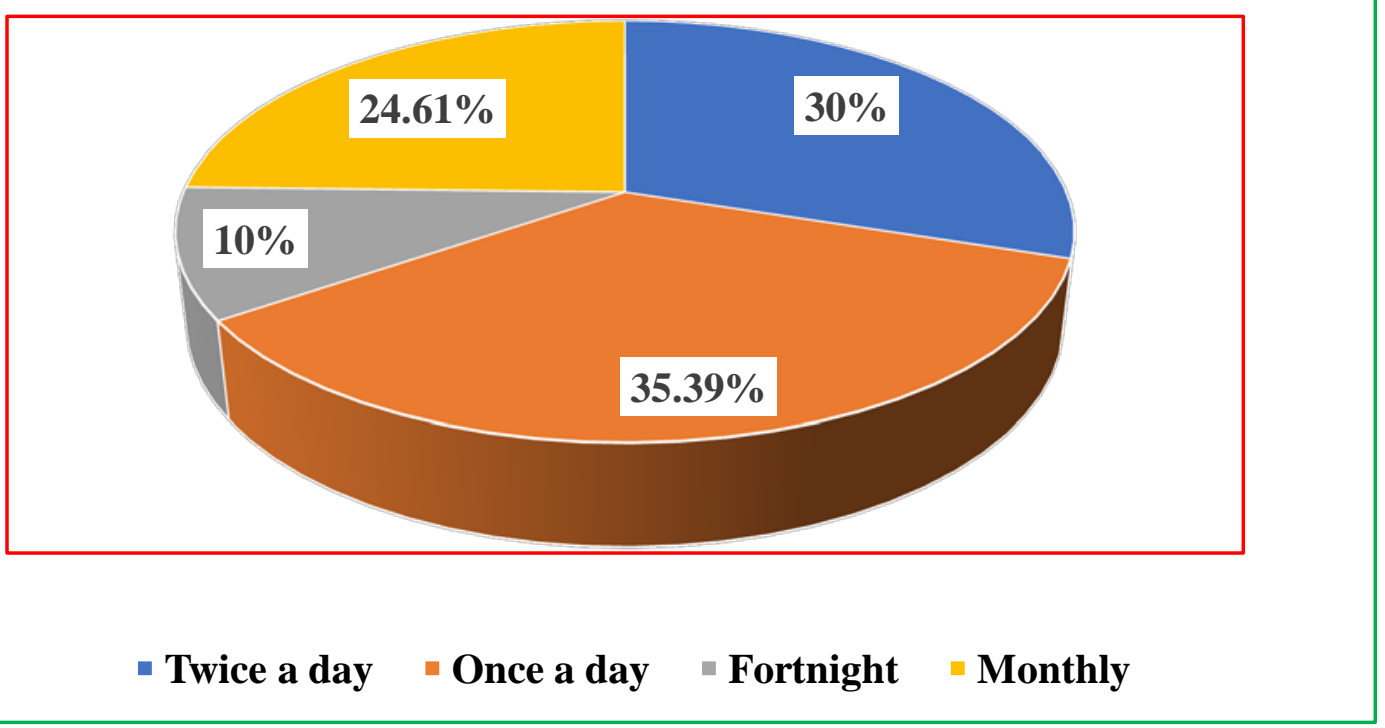

Table 1.2 shows the women' frequency to use Patanjali’s personal care products and reveal that majority of the women (35.39\%) use Patanjali's personal care products on daily basis. $30 \%$ women use these products two to times in a day whereas $10 \%$ use these products fortnightly. A big portion of women respondents (24\%) use personal care products of Patanjali on monthly basis. 
Table-1.3

\begin{tabular}{|l|l|l|}
\hline $\begin{array}{l}\text { Awareness Level About Patanjali's } \\
\text { personal Care Products }\end{array}$ & Frequency & Percent \\
\hline $80-100 \%$ & 52 & $40 \%$ \\
\hline $60-80 \%$ & 38 & $29 \%$ \\
\hline $40-60 \%$ & 30 & $23 \%$ \\
\hline $20-40 \%$ & 6 & $5 \%$ \\
\hline Less than 20\% & 4 & $3 \%$ \\
\hline Total & 130 & $100.0 \%$ \\
\hline
\end{tabular}

\section{Awareness Level About Patanjali’s personal Care} Products

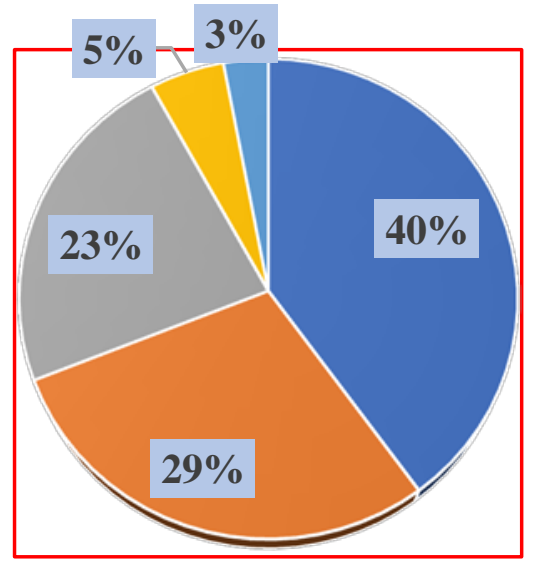

$-80-100 \%-60-80 \% \quad-40-60 \% \quad-20-40 \% \quad-$ Less than $20 \%$

Table 1.3reveals the awareness level of women regarding Patanjali’s personal care products. Results shows that majority of the women respondents (40\%) have excellent knowledge about the personal care products of Patanjali followed by $29 \%$ and $23 \%$ women who have extremely good and fairawareness respectively. Whereas only 5\% women are there who are very less aware and 3\% women are hardly aware about the Patanjali's personal care products.

Table-1.4

\begin{tabular}{|l|l|l|}
\hline $\begin{array}{l}\text { Sources of Awareness about } \\
\text { Patanjali's personal Care Products }\end{array}$ & Frequency & Percent \\
\hline TV \&Print Media & 81 & $62.30 \%$ \\
\hline Radio & 7 & $5.38 \%$ \\
\hline
\end{tabular}




\begin{tabular}{|l|l|l|}
\hline Social Media & 25 & $19.24 \%$ \\
\hline Billboards & 5 & $3.84 \%$ \\
\hline Online Marketing & 12 & $9.24 \%$ \\
\hline Total & 130 & $100.0 \%$ \\
\hline
\end{tabular}

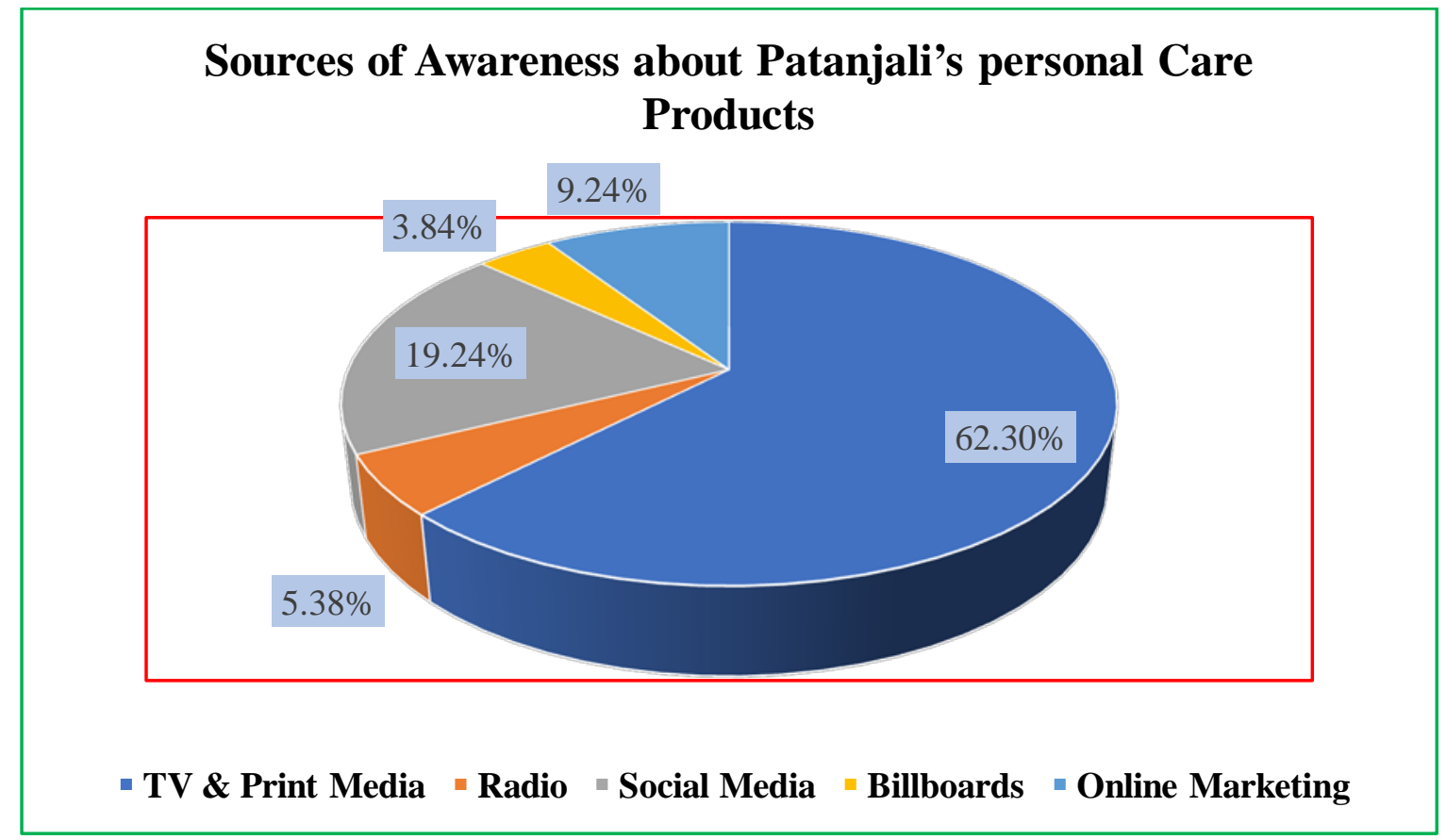

Table 1.4reveals the sources of awareness about Patanjali's personal care products. Results indicate that majority of the women respondents (62.30\%) get aware through TV \& Print Media about the personal care products of Patanjali followed by social media (19.24\%) and Online Marketing (9.24\%). Whereas Radio (5.38\% and Billboards (3.84\%) play a very nominal role for women as a source of awareness towardsPatanjali’s personal care products.

\section{$\underline{\text { Table-1.5 }}$}

\begin{tabular}{|l|l|l|}
\hline $\begin{array}{l}\text { Motivational Factors to } \\
\text { PurchasePatanjali's personal Care } \\
\text { Products }\end{array}$ & Frequency & Percent \\
\hline Prices of the products & 75 & $58 \%$ \\
\hline Quality of the products & 85 & $65 \%$ \\
\hline Baba Ramdev (Brand Ambassador) & 67 & $52 \%$ \\
\hline It is Swadeshi & 90 & $69 \%$ \\
\hline Easily Available at every place & 60 & $46 \%$ \\
\hline
\end{tabular}




\section{Motivational Factors to Purchase Patanjali’s Personal Care Products}

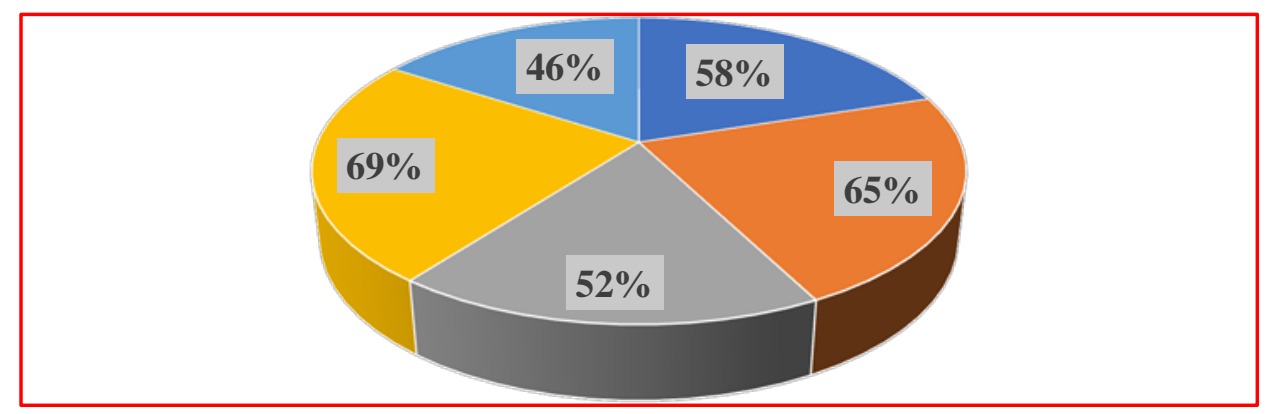

- Prices of the products

- Quality of the products

- Baba Ramdev (Brand Ambassador)

It is Swadeshi

- Easily Available at every place

Table 1.5 reveals the various factors which motivate women to purchase Patanjali's personal care products. Results indicate that majority of the women (69\%) purchase Patanjali products as it is Swadeshi company. They also considered Quality (65\%) and Price (58\%) of the Patanjali products as a motivational Factor to purchase personal care products respectively. The name of Patanjali Brand Ambassador Baba Ramdev is also considered as a motivational factor for women due to which they prefer to purchase these products.

\section{Hypotheses Testing:}

Ho (1): All the women have same perception towards personal care products of Patanjali Ayurveda Ltd.

Ho (1a):All the women have same perception that the Patanjali FMCG products are superior in quality amongst all the brands available in the market.

$\underline{\text { Table-1.6 }}$

\begin{tabular}{|c|c|c|c|c|c|}
\hline $\begin{array}{l}\text { Perception } \\
\text { towards Quality }\end{array}$ & $\begin{array}{l}\text { Frequency } \\
\text { (Observed) }\end{array}$ & $\begin{array}{l}\text { Frequency } \\
\text { (Expected) }\end{array}$ & $\begin{array}{c}\text { Residual } \\
\text { Value }\end{array}$ & $\begin{array}{l}\text { Chi- } \\
\text { Square }\end{array}$ & $\begin{array}{c}\mathbf{P} \\
\text { Value }\end{array}$ \\
\hline Strongly Agree & 43 & 26 & 17 & \multirow{4}{*}{$68.28^{\mathrm{a}}$} & \\
\hline Agree & 49 & 26 & 23 & & \\
\hline Neutral & 29 & 26 & 3 & & $0.002 *$ \\
\hline Disagree & 8 & 26 & -18 & & \\
\hline
\end{tabular}




\begin{tabular}{|c|c|c|c|c|} 
Strongly Disagree & 1 & 26 & -25 & \\
\hline Total & $\mathbf{1 3 0}$ & & & \\
\hline
\end{tabular}

Df-4

$$
\chi 2=68.28
$$

$\mathrm{p}=0.01$

Results: Table 1.6 reveals that the value of chi-square is $\chi 2=68.28$ and $p=0.002$ which is less than .05 so we reject the null hypothesis and conclude that there is a significant difference among the perception of women regarding the statement that the Patanjali FMCG products are superior in quality amongst all the brands available in the market. Majority of the women are agreed on this statement whereas a big number of the women respondents have nothing to say about this statement.

Ho(1b): All the women have same perception that products of Patanjali have no side effects.

$\underline{\text { Table-1.7 }}$

\begin{tabular}{|c|c|c|c|c|c|}
\hline $\begin{array}{c}\text { Perception } \\
\text { towards Quality }\end{array}$ & $\begin{array}{l}\text { Frequency } \\
\text { (Observed) }\end{array}$ & $\begin{array}{l}\text { Frequency } \\
\text { (Expected) }\end{array}$ & $\begin{array}{l}\text { Residual } \\
\text { Value }\end{array}$ & $\begin{array}{l}\text { Chi- } \\
\text { Square }\end{array}$ & $\begin{array}{c}\mathbf{P} \\
\text { Value }\end{array}$ \\
\hline Strongly Agree & 39 & 26 & 13 & \multirow{5}{*}{ 98.68a } & \multirow{5}{*}{$0.000 *$} \\
\hline Agree & 62 & 26 & 36 & & \\
\hline Neutral & 18 & 26 & -8 & & \\
\hline Disagree & 10 & 26 & -16 & & \\
\hline Strongly Disagree & 1 & 26 & -25 & & \\
\hline Total & 130 & & & & \\
\hline
\end{tabular}
Df-4
$\chi 2=98.68$
$\mathrm{p}=0.000$

Results: Table 1.7 reveals that the value of chi-square is $\chi 2=98.68$ and $p=0.000$ which is less than 0.05 so we reject the null hypothesis and conclude that there is a significant difference among the perception of women regarding the statement that the Patanjali FMCG products have no side effect and does not harm their health. Majority of the women perceive that Patanjali products contains ayurvedic ingredientdue to which it will not harm our health. On the other hand, many other women showing neutral attitude on this statement and not prefer to answer it. Thus, all the women have different perception towards the side effect of Patanjali's personal care products. 
Ho(1c): All the women perceive that Patanjali products have appealing and attractive packaging.

$\underline{\text { Table-1.8 }}$

\begin{tabular}{|c|c|c|c|c|c|}
\hline $\begin{array}{l}\text { Perceptiontowards } \\
\text { Product's appealing } \\
\text { and attractive } \\
\text { packaging }\end{array}$ & $\begin{array}{l}\text { Frequency } \\
\text { (Observed) }\end{array}$ & $\begin{array}{l}\text { Frequency } \\
\text { (Expected) }\end{array}$ & $\begin{array}{c}\text { Residual } \\
\text { Value }\end{array}$ & $\begin{array}{l}\text { Chi- } \\
\text { Square }\end{array}$ & $\begin{array}{c}\mathbf{P} \\
\text { Value }\end{array}$ \\
\hline Strongly Agree & 35 & 26 & 9 & \multirow{5}{*}{$29.22 \mathrm{a}$} & \multirow{5}{*}{$0.000 *$} \\
\hline Agree & 37 & 26 & 11 & & \\
\hline Neutral & 33 & 26 & 7 & & \\
\hline Disagree & 21 & 26 & -5 & & \\
\hline Strongly Disagree & 4 & 26 & -22 & & \\
\hline Total & 130 & & & & \\
\hline
\end{tabular}
Df-4
$\chi 2=29.22$
$\mathrm{p}=0.000$

Results: Table 1.8shows that the value of chi-square is $\chi^{2}=29.22$ and $p=0.000$ which is less than 0.05 so we reject the null hypothesis and conclude that there is a significant difference among the perception of women regarding the statement that Patanjali Products has appealing and attractive packaging. all the women have different perception towards Patanjali's personal care products packaging. Many women see these products' packaging very attractive and appealing so that they want to buy the products whereas some women don't find products’ packaging attractive and buy them due to its quality and price.

Ho(1d): All the women perceive that the label description of Patanjali FMCG products is providing complete and accurate information to its consumers.

Table-1.9

\begin{tabular}{|l|c|c|c|c|c|}
\hline $\begin{array}{l}\text { Perceptiontowards } \\
\text { Accuracy of Label } \\
\text { Description }\end{array}$ & $\begin{array}{l}\text { Frequency } \\
\text { (Observed) }\end{array}$ & $\begin{array}{l}\text { Frequency } \\
\text { (Expected) }\end{array}$ & $\begin{array}{c}\text { Residual } \\
\text { Value }\end{array}$ & $\begin{array}{l}\text { Chi- } \\
\text { Square }\end{array}$ & $\begin{array}{c}\text { P } \\
\text { Value }\end{array}$ \\
\hline
\end{tabular}




\begin{tabular}{|c|c|c|c|c|c|}
\hline Strongly Agree & 28 & 26 & 2 & \multirow{5}{*}{$69.21 \mathrm{a}$} & \multirow{5}{*}{$0.003 *$} \\
\hline Agree & 56 & 26 & 30 & & \\
\hline Neutral & 34 & 26 & 8 & & \\
\hline Disagree & 10 & 26 & -16 & & \\
\hline Strongly Disagree & 02 & 26 & -24 & & \\
\hline Total & 130 & & & & \\
\hline
\end{tabular}
Df-4
$\chi 2=69.21$
$\mathrm{p}=0.000$

Results: Table 1.9 shows that the value of chi-square is $\chi 2=69.21$ and $p=0.003$ which is less than 0.05 so we reject the null hypothesis and conclude that there is a significant difference among the perception of women regarding label description of Patanjali's personal care products. Majority of the women agree with this statement that the label description pasted on the products provide complete and accurate information to its consumers whereas some women don’t have anything to say about it.

Ho (2): All the women have same reason to prefer personal care products of Patanjali Ayurveda Ltd.

Ho (2a): All the women preferPatanjali's personal care products because of its good quality.

Table-1.10

\begin{tabular}{|c|c|c|c|c|c|}
\hline $\begin{array}{l}\text { Prefer the product } \\
\text { due to its quality }\end{array}$ & $\begin{array}{l}\text { Frequency } \\
\text { (Observed) }\end{array}$ & $\begin{array}{l}\text { Frequency } \\
\text { (Expected) }\end{array}$ & $\begin{array}{l}\text { Residual } \\
\text { Value }\end{array}$ & $\begin{array}{l}\text { Chi- } \\
\text { Square }\end{array}$ & $\begin{array}{c}\mathbf{P} \\
\text { Value }\end{array}$ \\
\hline Strongly Agree & 52 & 26 & 26 & \multirow{5}{*}{ 117.91a } & \multirow{5}{*}{$0.003 *$} \\
\hline Agree & 59 & 26 & 33 & & \\
\hline Neutral & 16 & 26 & -10 & & \\
\hline Disagree & 2 & 26 & -24 & & \\
\hline Strongly Disagree & 1 & 26 & -25 & & \\
\hline Total & 130 & & & & \\
\hline
\end{tabular}


Df-4

$\chi 2=117.91$

$\mathrm{p}=0.003$

Results: Table 1.10reveals that the value of chi-square is $\chi 2=117.91$ and $p=0.003$ which is less than 0.05 so we reject the null hypothesis and conclude that all the women of the present study don't prefer the products of the Patanjali only because of its good quality. There may be many reasons i.e. its price, its' brand name, it's availability and it is ayurvedic etc. Thus, all the women have different reason to prefer Patanjali's personal care products and Quality is one of them.

Ho (2b): All the women preferPatanjali's personal care products because its provides Large Variety of chemical free products.

$\underline{\text { Table-1.11 }}$

\begin{tabular}{|c|c|c|c|c|c|}
\hline $\begin{array}{l}\text { Prefer the product } \\
\text { due to its large } \\
\text { variety of chemical } \\
\text { free }\end{array}$ & $\begin{array}{l}\text { Frequency } \\
\text { (Observed) }\end{array}$ & $\begin{array}{l}\text { Frequency } \\
\text { (Expected) }\end{array}$ & $\begin{array}{l}\text { Residual } \\
\text { Value }\end{array}$ & $\begin{array}{l}\text { Chi- } \\
\text { Square }\end{array}$ & $\begin{array}{c}\mathbf{P} \\
\text { Value }\end{array}$ \\
\hline Strongly Agree & 32 & 26 & 6 & \multirow{5}{*}{ 108.98a } & \multirow{5}{*}{$0.004 *$} \\
\hline Agree & 68 & 26 & 42 & & \\
\hline Neutral & 23 & 26 & -3 & & \\
\hline Disagree & 6 & 26 & -20 & & \\
\hline Strongly Disagree & 1 & 26 & -25 & & \\
\hline Total & 130 & & & & \\
\hline
\end{tabular}

Df-4

$\chi 2=108.98$

$\mathrm{p}=0.004$

Results: Table 1.11reveals that the value of chi-square is $\chi^{2}=108.98 a n d p=0.004$ which is less than 0.05 so we reject the null hypothesis and conclude thatmajority of the women of the present study prefer Patanjali's personal care products as they provide large variety of chemical free products whereas a small number of the women in the present study don't consider this factor while prefer Patanjali's personal care products. They may have their other 
reason to prefer Patanjali's personal care products and this reason is not considerable for them.

Ho (2c): All the women preferPatanjali's personal care products because Patanjali offers fair price to all the products.

$\underline{\text { Table-1.12 }}$

\begin{tabular}{|c|c|c|c|c|c|}
\hline $\begin{array}{l}\text { Prefer the product } \\
\text { due to its fair price }\end{array}$ & $\begin{array}{l}\text { Frequency } \\
\text { (Observed) }\end{array}$ & $\begin{array}{l}\text { Frequency } \\
\text { (Expected) }\end{array}$ & $\begin{array}{l}\text { Residual } \\
\text { Value }\end{array}$ & $\begin{array}{l}\text { Chi- } \\
\text { Square }\end{array}$ & $\begin{array}{c}\mathbf{P} \\
\text { Value }\end{array}$ \\
\hline Strongly Agree & 39 & 26 & 13 & \multirow{5}{*}{ 96.38a } & \multirow{5}{*}{$0.000 *$} \\
\hline Agree & 62 & 26 & 36 & & \\
\hline Neutral & 22 & 26 & -4 & & \\
\hline Disagree & 6 & 26 & -20 & & \\
\hline Strongly Disagree & 1 & 26 & -25 & & \\
\hline Total & 130 & & & & \\
\hline
\end{tabular}

Df-4

$\chi 2=96.38$

$\mathrm{p}=0.000$

Results: Table 1.12reveals that the value of chi-square is $\chi 2=96.38 \mathrm{and} p=0.000$ which is less than 0.05 so we reject the null hypothesis and conclude that majority of the women consider price as an effective factor due to which they prefer Patanjali's personal care products. They say that Patanjali provide its products in fair prices so that they prefer to buy these products whereas a small number of the women in the present study don't consider this factor very important and said quality of the product is more important than fair price. Thus, all the women have different reasons to prefer Patanjali’s personal care products.

Ho (2d): All the women preferPatanjali's personal care products because these are easily available in the market. 
$\underline{\text { Table-1.13 }}$

\begin{tabular}{|c|c|c|c|c|c|}
\hline $\begin{array}{l}\text { Prefer the product } \\
\text { due to its easy } \\
\text { availability }\end{array}$ & $\begin{array}{l}\text { Frequency } \\
\text { (Observed) }\end{array}$ & $\begin{array}{l}\text { Frequency } \\
\text { (Expected) }\end{array}$ & $\begin{array}{l}\text { Residual } \\
\text { Value }\end{array}$ & $\begin{array}{l}\text { Chi- } \\
\text { Square }\end{array}$ & $\begin{array}{c}\mathbf{P} \\
\text { Value }\end{array}$ \\
\hline Strongly Agree & 39 & 26 & 13 & \multirow{5}{*}{$115.68 \mathrm{a}$} & \multirow{5}{*}{$0.000^{*}$} \\
\hline Agree & 67 & 26 & 41 & & \\
\hline Neutral & 19 & 26 & -7 & & \\
\hline Disagree & 4 & 26 & -22 & & \\
\hline Strongly Disagree & 1 & 26 & -25 & & \\
\hline Total & 130 & & & & \\
\hline
\end{tabular}

Df-4 $\quad \chi^{2}=115.68 \quad \mathrm{p}=0.000$

Results: Table 1.13reveals that the value of chi-square is $\chi 2=115$.68and $p=0.000$ which is less than 0.05 so we reject the null hypothesis and conclude that there are significant differences among the women regarding their reasons of preferring Patanjali's personal care products. They not only prefer the products due to its easy availability in the market but alsobecause of its brand name, quality, quantity, price and swadeshi concept.

Ho (3): The awareness level does not differ significantly among the women regarding personal care products of Patanjali Ayurveda Ltd.

Table-1.14

\begin{tabular}{|c|c|c|c|c|c|}
\hline $\begin{array}{l}\text { Awareness Level } \\
\text { About Patanjali's } \\
\text { personal Care } \\
\text { Products } \\
\end{array}$ & $\begin{array}{l}\text { Frequency } \\
\text { (Observed) }\end{array}$ & $\begin{array}{l}\text { Frequency } \\
\text { (Expected) }\end{array}$ & $\begin{array}{l}\text { Residual } \\
\text { Value }\end{array}$ & $\begin{array}{l}\text { Chi- } \\
\text { Square }\end{array}$ & $\begin{array}{c}\mathbf{P} \\
\text { Value }\end{array}$ \\
\hline $80-100 \%$ & 52 & 26 & 26 & \multirow{5}{*}{$69.23 a$} & \multirow{5}{*}{$0.000 *$} \\
\hline $60-80 \%$ & 38 & 26 & 14 & & \\
\hline $40-60 \%$ & 30 & 26 & 4 & & \\
\hline $20-40 \%$ & 6 & 26 & -20 & & \\
\hline Less than $20 \%$ & 4 & 26 & -22 & & \\
\hline Total & 130 & & & & \\
\hline
\end{tabular}


Df-4

$\chi 2=69.23$

$\mathrm{p}=0.000$

Results: Table 1.14reveals that the value of chi-square is $\chi 2=69.23$ and $p=0.000$ which is less than 0.05 so we reject the null hypothesis and conclude that there are significant differences among the awareness level of women regarding Patanjali's personal care products. They may be differing in their awareness level due to their education, interest, lack of promotional strategies etc.

Ho (4): All the women get motivated by the same factor to purchase personal care products of Patanjali Ayurveda Ltd.

Table-1.15

\begin{tabular}{|c|c|c|c|c|c|}
\hline $\begin{array}{l}\text { Motivational Factors to } \\
\text { Purchase Patanjali's personal } \\
\text { Care Products }\end{array}$ & Frequency & $\begin{array}{l}\text { Frequency } \\
\text { (Expected) }\end{array}$ & $\begin{array}{l}\text { Residual } \\
\text { Value }\end{array}$ & $\begin{array}{l}\text { Chi- } \\
\text { Square }\end{array}$ & $\begin{array}{c}\mathbf{P} \\
\text { Value }\end{array}$ \\
\hline Prices of the products & 75 & 130 & -55 & \multirow{5}{*}{$119.38 \mathrm{a}$} & \multirow{5}{*}{$0.000 *$} \\
\hline Quality of the products & 85 & 130 & -45 & & \\
\hline $\begin{array}{l}\text { Baba Ramdev (Brand } \\
\text { Ambassador) }\end{array}$ & 67 & 130 & -63 & & \\
\hline It is Swadeshi & 90 & 130 & -40 & & \\
\hline Easily Available at every place & 60 & 130 & -70 & & \\
\hline
\end{tabular}

Df-4 $\quad \chi^{2}=119.38 \quad \mathrm{p}=0.000$

Results: Table 1.15reveals that the value of chi-square is $\chi 2=119.38$ and $\mathrm{p}=0.000$ which is less than 0.05 so we reject the null hypothesis and conclude that there are significant differences among the women regarding various factors which motivate them to purchase personal care products of Patanjali Ayurveda Ltd. Majority of the women motivate to purchase the products by the quality of the products and its swadeshi concepts. Women also considered Patanjali’s products fair price and Yoga Guru Baba Ramdev’s name as motivating factors to purchase personal care products of Patanjali Ayurveda Ltd.

\section{Findings and Discussions:}

The present study reveals that the majority of the women respondents are under 25-35 years. Results of the study also reveals that majority of the women in present study use Patanjali's personal care products on daily basis. The present study also indicated that majority of the 
women are highly aware about the Patanjali personal care products and TV \& social media are the major sources of their awareness. The study also reveals that the quality and price of the products, Patanjali's swadeshi concept and Yoga Guru Baba Ramdev's name play major role as motivator factors due to which women purchase personal care products of Patanjali. Present study also reveals that the perception and preferences of the women are differ in regards to the quality of the product, price of the product, side effect due to use of the products, product's attractive packaging and true information on product label provided by the company etc.

\section{Limitations of the study:}

The sample used for the present study may not be justifiable to generalize the findings to all the women who are using personal care products of Patanjali Ayurveda Ltd. The present study isbased on accidental sampling which is non-probability in nature thus the results can't be generalise to the whole women population living in Haridwar district as all the Patanjali stores were not covered during the present study.

\section{Conclusion:}

The study identified that Patanjali Ayurveda Limited has been created a strong brand image among the women due to many factors which includes product quality, price, quantity, easily availability and its swadeshi concept. The name of brand ambassador Yoga Guru Baba Ramdev is also a motivating factor which encourage consumer to purchase Patanjali products. The price of the products is so fair and cheap that it fits in the pockets of the consumers. The study also revealed that women consumers of Patanjali Ayurveda Limited are highly aware about the personal care products and prefer to buy these products due to its quality natural ingredients. Majority of the Women in the study perceived that the personal care products of Patanjali will not harm their health as it is chemical free. They also believe that all the information provided by the company is accurate that's why women prefer to buy the products of Patanjali and becoming loyal day by day towards personal care products of Patanjali Ayurveda Limited. The researcher has finally concluded that the Indian women are growing more and more brand conscious when it comes to purchasing personal care products especially cosmetics. Furthermore, Patanjali Ayurveda Limited needs to work on their marketing strategies as it plays a biggest role in promoting the products and effect the perception and attitude of the consumer towards purchasing the products. 


\section{Bibliography:}

- Ali, M. I., \& Yadav, M. (2015). A study of consumer perception of herbal products in Bhopal. International Journal Of Management Studies, 2(1), 69-80.

- Archer, T.M. (2003) Web-based surveys. Journal of Extension, 41, 1-5.

- Ashok Yakkaldevi (2013), Consumer Behavior among Women with special reference to Cosmetics, International Journal of Interdisciplinary and Multidisciplinary Studies, $1(1), 1-5$

- Gunn, H. (2002) Web-based surveys: changing the survey process. First Monday, 7(12), 1-14 (2 December 2002) (online version).

- Ilieva, J., Baron, S. \& Healey, N. (2002) Online surveys in marketing research: prosand cons. International Journal of Market Research, 44, 361-376.

- Kent, R. \& Lee, M. (1999) Using the Internet for market research: a study of privatetrading on the Internet. Journal of the Market Research Society, 41, 377-386.

- Khanna, R. (2015). Customer perception towards brand: a study onPatanjali.Global journal of management and business research: e marketing, 15(9), 41-45.

- Lokken, S. L., et al., (2003). Comparing online and non-online shoppers.International Journal of Consumer Studies, 27 (2 March), 126-133.

- Mehta, R. \&Sivadas, E. (1995) Comparing responses rates and response content inmail versus electronic mail surveys. Journal of the Market Research Society, $37,429-440$.

- Neuman, L.W. (2004) Basics of Social Research: Qualitative and QuantitativeApproaches. Pearson, Boston, New York, San Francisco.

- Shinde, D. T., \& Gharat, S. J. (2017). Product positioning of Patanjali Ayurveda ltd.Pune research discovery, 1(3), 1-6.

- Sundari, R., \&MURUGAN, S.M. (2011). Brand Loyalty’s Influence on Women's Buying Behavior with Special Reference to Personal Care Products, International Journal of Research in Commerce, It \& Management, 1(2), 57-62.

- TarangVaish(2006), Impacts of Health and Environmental Consciousness on Young Female Consumers' Attitude towards and Purchase of Natural Beauty Products, International Journal of Consumer Studies, 33(6), 627-638.

- Urvashi Makkar (2007), Changing Attitude of Consumers from Chemical to Herbal Cosmetics in India, Indian Journal of Marketing, 9. 


\section{WEBSITES}

- http://en.wikipedia.org/wiki/foreign branded cosmetics.

- http://www.indianmirror.com/indianindustries/cosmetics.html

- http://www.cosmeticaitalia.it/foreign-cosmetic-industry.html

- http://www.cosmotech expoindia.com/india-cosmetic-market

- https://en.wikipedia.org/wiki/Patanjali_Ayurved 